\title{
The Analysis of Musculoskeletal Complaints and the Influencing Factors on Shoe-Craftsmen in Leather Crafs Center, Magetan
}

\author{
Ekawati Wasis Wijayati ${ }^{1}$, \\ Nurwijayanti $^{2}$, Koesnadi ${ }^{2}$ \\ ${ }^{1}$ Student of Public Health \\ Postgraduate Program STIKes \\ Surya Mitra Husada \\ ${ }^{2}$ Lecturer of Public Health \\ Postgraduate Program STIKes \\ Surya Mitra Husada \\ ekawati.wasis@gmail.com
}

\begin{abstract}
Working posture that is not appropriately done and maintained in long period/ duration can cause complaints or health problems, especially musculoskeletal complaints. The emergence of musculoskeletal complaints can lead to fatigue and even concentration disorder in working that can result in decreasing of working productivity. The purpose of this study is to analyze musculoskeletal complaints and the influencing factors on shoe-craftsmen in Magetan leather craft center. The research design that is used is quantitative research using analytic observational method and cross sectional approach. The sampling technique is proportional qluster random sampling with 84 respondents of shoescraftsmen in Sawo Magetan leather craft center. The data of the research were analyzed by ordinal regression test. The result of statistical analysis using ordinal regression shows that $\mathrm{p}$ value $=0,000(\mathrm{p}<0,05)$ which means there is influence of working posture, duration, period of work, body size / BMI toward musculoskeletal complaints on shoecraftsmen Magetan leather craft center. The strongest influence is working posture, period of work and duration. High-risk working postures that is performed continuously over a long period of time will increase the risk of musculoskeletal complaints, so it is necessary to take corrective action posture with ergonomic considerations.
\end{abstract}

Keywords : Body Size/BMI, Duration, Musculoskeletal Complaints, Period of Work, Shoe-Crafsmen, Working Posture.

Published : May 11, 2018

Copyright $\odot 2018$ STIKes Surya Mitra Husada

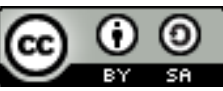

This is an open-acces article distributed under the terms of the Creative Commons Attribution-ShareAlike 4.0 International License. 


\section{INTRODUCTION}

Work attitudes that humans often do in their work can be done by standing, sitting, squatting, walking, and so forth. Condition of means / tools employed can affect a person's work postures in carrying out his work. Work posture is a regulation of posture at work (Bridger, 1995 in Alfara, et al, 2017). If the work posture is not done properly and maintained in a relatively long period of time, it can lead to complaints or health problems, especially musculoskeletal complaints. Musculoskeletal disorders are a set of symptoms associated with muscle tissue, tendons, ligaments, cartilages, nervous system, bone structure, and blood vessels (Tarwaka, 2004 in Alfara, et al, 2017).

Posture work as one of the factors causing the occurrence of musculoskeletal complaints need to get attention because it relates to one's work process. Based on the results of research by Alfara et al (2017) on the assembly operator in Yessy Shoes home industry, showed that the process of assembling shoes with available work facilities forced workers to work with the wrong posture and the attitude was done repeatedly during the duration of working time that impacted pain in certain body parts.

Unnatural/false work postures that occur over long periods of time can result in musculoskeletal complaints and other disorders that may even decrease a worker's productivity. Based on the research of Yustica, et al (2016) at the Tembalang toll gate of Semarang, from 30 toll guards mostly 14 (46.7\%) felt mild musculoskeletal complaints caused by the sitting position of workers who tend to lean forward with posture score work is.

Initial survey on November 12, 2017 shows that the existing industry in Sawo Magetan street leather craft centers produce various types of shoes and sandals models. In the process of shoe and sandal workmanship is done manually with the working attitude of sitting that is considered less ergonomic because the worker performs a less precise and repetitive posture, ie posture leaning / bending. And based on interviews on 6 people shoe craftsmen, as many as 4 people said often feel pain and stiffness after working on certain body parts such as neck, shoulders, arms, back, waist, and legs.

Seeing the condition of the field as has been described, the researchers are interested to perform the analysis of Musculoskeletal Complaints And Factors Affecting On Craftsmen Workers Shoes At Magetan Leather Handicraft Center.

\section{METHOD}

This research is a quantitative research with analytic observational method and using cross sectional approach, where the data collection process is done simultaneously at the same time (Sugiyono, 2012). The data collection was done at Sawo Magetan leather craft center on January 19 until February 10, 2018.

The sample in this research is the worker of shoe craftsman in leather craft center Magetan. Of the population of 106 people selected as many as 84 people as samples taken with proportional technique qluster random sampling.

The instrument used for data collection is the RULA worksheet, an assessment sheet used to measure the risk of work posture against musculoskeletal complaints and NBM questionnaires, a questionnaire used to assess the level of musculoskeletal complaints combined with contents to measure duration, period of service and size body / BMI. The data has been obtained then tested statistically with ordinal regression to analyze the influence between independent variables to the dependent variable. Where independent variable in this research is work posture, duration, period of work, body size / IMT, while the dependent variable is musculoskeletal complaint. 


\section{RESULTS}

Based on the results of research conducted from 19 January to 10 February 2018 on 84 respondents, obtained the following results:

\section{Characteristics Of Research Variables}

Table 1. Frequency Distribution of Musculoskeletal Complaints In Shoe Craftsmen Workers In Leather Craft Centre Magetan

\begin{tabular}{|c|c|c|}
\hline Musculoskeletal complaint & Frequency & $\%$ \\
\hline Low & 21 & 25,0 \\
\hline Medium & 45 & 53,6 \\
\hline High & 18 & 21,4 \\
\hline Very high & 0 & 0 \\
\hline Total & 84 & 100 \\
\hline
\end{tabular}

The table shows that of 84 respondents, most of them (45 respondents or 53,6\%) experience musculoskeletal complaints with medium risk category.

Table 2. Frequency Distribution of Work Posture In Shoe Craftsmen Workers In Leather Craft Centre Magetan

\begin{tabular}{|c|c|c|}
\hline Working posture risk & Frequency & $\%$ \\
\hline Low & 0 & 0 \\
\hline Medium & 31 & 36,9 \\
\hline High & 39 & 46,4 \\
\hline Very high & 14 & 16,7 \\
\hline Total & 84 & 100 \\
\hline
\end{tabular}

The table shows that of 84 respondents, most of them work with unnatural working posture with high working posture risk. There are 39 respondents $(46,4 \%)$.

Table 3. Frequency Distribution of Duration In Shoe Craftsmen Workers In Leather Craft Centre Magetan

\begin{tabular}{lccc}
\hline & Duration & Frequency & \% \\
\hline Short & & 26 & 31 \\
Medium & & 37 & 44 \\
Long & Total & 21 & 25 \\
\hline & & 84 & 100 \\
\hline
\end{tabular}

The table shows that of 84 respondents, most of them (37 respondents or 44\%) with medium category of unnatural working posture ( $1-2$ hours/day). 
Table 4. Frequency Distribution of Period of Work In Shoe Craftsmen Workers In Leather Craft Centre Magetan

\begin{tabular}{lccc}
\hline & Period of work & Frequency & \% \\
\hline$<5$ & & 13 & 15,5 \\
$5-10$ & 22 & 26,2 \\
$>10$ & Total & 49 & 58,3 \\
\hline & & 84 & 100 \\
\hline
\end{tabular}

The table shows that of 84 respondents, most of them (49 respondents or 58,3\%) have more than 10 period of work.

Table 5. Frequency Distribution of Body Size/ BMI In Shoe Craftsmen Workers In Leather Craft Centre Magetan

\begin{tabular}{lccc}
\hline & Body Size/BMI & Frequency & \% \\
\hline Underweight & & 17 & 20,2 \\
Normal & 64 & 76,2 \\
Overweight & Total & 3 & 3,6 \\
\hline & & 84 & 100 \\
\hline
\end{tabular}

The table shows that of 84 respondents, most respondents 64 respondents or $76,2 \%$ are in normal category.

\section{BIVARIATE ANALYSIS}

Table 6. Cross-tabulation Between Work Posture With Musculoskeletal Complaints In Craftsmen Workers In The Center Of Magetan Leather Craft

\begin{tabular}{|c|c|c|c|c|c|c|c|}
\hline & & & \multicolumn{4}{|c|}{ Muskuloskeletal complaints } & \multirow{2}{*}{ Total } \\
\hline & & & Low & Medium & High & Very high & \\
\hline \multirow{7}{*}{$\begin{array}{l}\text { Work } \\
\text { Posture }\end{array}$} & Low & $\sum$ & 0 & 0 & 0 & 0 & 0 \\
\hline & \multirow{2}{*}{ Medium } & $\sum$ & 18 & 12 & 1 & 0 & 31 \\
\hline & & $\%$ & 21,4 & 14,3 & 1,2 & 0 & 36,9 \\
\hline & \multirow{2}{*}{ High } & $\sum$ & 3 & 30 & 6 & 0 & 39 \\
\hline & & $\%$ & 3,6 & 35,7 & 7,1 & 0 & 46,4 \\
\hline & \multirow{2}{*}{ Very high } & $\sum$ & 0 & 3 & 11 & 0 & 14 \\
\hline & & $\%$ & 0 & 3,6 & 13,1 & 0 & 16,7 \\
\hline \multirow{2}{*}{\multicolumn{2}{|c|}{ Total }} & $\sum$ & 21 & 45 & 18 & 0 & 84 \\
\hline & & $\%$ & 25 & 53,6 & 21,4 & 0 & 100 \\
\hline \multicolumn{3}{|c|}{ Chi-Square } & \multicolumn{5}{|c|}{$P=0,000(p<0,05)$} \\
\hline
\end{tabular}

The table shows that respondents with high category work postures as many as 30 people $(35.7 \%)$ feel the musculoskeletal complaints of the medium category. The result of statistical test with Chi-Square shows $p$ value $=0.000$, where $p<0,05$, meaning there is significant influence of work posture to musculoskeletal complaint. 
Table 7. Cross tabs Between Duration With Musculoskeletal Complaints In Craftsmen Workers In The Center Of Magetan Leather Craft

\begin{tabular}{|c|c|c|c|c|c|c|c|}
\hline & & & \multicolumn{4}{|c|}{ Muskuloskeletal complaints } & \multirow{2}{*}{ Total } \\
\hline & & & Low & Medium & High & Very high & \\
\hline \multirow[t]{6}{*}{ Duration } & \multirow{2}{*}{ Short } & $\sum$ & 15 & 11 & 0 & 0 & 26 \\
\hline & & $\%$ & 17,9 & 13,1 & 0 & 0 & 31 \\
\hline & \multirow{2}{*}{ Medium } & $\sum$ & 6 & 26 & 5 & 0 & 37 \\
\hline & & $\%$ & 7,1 & 31 & 6 & 0 & 37 \\
\hline & \multirow{2}{*}{ Long } & $\sum$ & 0 & 8 & 13 & 0 & 21 \\
\hline & & $\%$ & 0 & 9,5 & 15,5 & 0 & 25 \\
\hline \multirow{2}{*}{\multicolumn{2}{|c|}{ Total }} & $\sum$ & 21 & 45 & 18 & 0 & 84 \\
\hline & & $\%$ & 25 & 53,6 & 21,4 & 0 & 100 \\
\hline \multicolumn{3}{|c|}{ Chi-Square } & \multicolumn{5}{|c|}{$P=0,000(p<0,05)$} \\
\hline
\end{tabular}

The table shows that most respondents with moderate category duration are as many as 26 people $(31 \%)$ feel musculoskeletal complaints of moderate category. In the Chi-Square test shows the value $\mathrm{p}=000$, where $\mathrm{p}<0.05$ which means there is a significant influence duration of musculoskeletal complaints.

Table 8. Cross-tabulation Between Working Periods With Musculoskeletal Complaints In Craftsmen Workers In The Center Of Magetan Leather Craft

\begin{tabular}{|c|c|c|c|c|c|c|c|}
\hline & & & \multicolumn{4}{|c|}{ Muskuloskeletal complaints } & \multirow{2}{*}{ Total } \\
\hline & & & Low & Medium & High & Very high & \\
\hline \multirow{6}{*}{$\begin{array}{l}\text { Working } \\
\text { Periods }\end{array}$} & \multirow{2}{*}{$<5$ th } & $\sum$ & 10 & 1 & 2 & 0 & 13 \\
\hline & & $\%$ & 11,9 & 1,2 & 2,4 & 0 & 15,5 \\
\hline & \multirow{2}{*}{$5-10$ th } & $\sum$ & 9 & 10 & 3 & 0 & 22 \\
\hline & & $\%$ & 10,7 & 11,9 & 3,6 & 0 & 26,2 \\
\hline & \multirow{2}{*}{$>10$ th } & $\sum$ & 2 & 34 & 13 & 0 & 49 \\
\hline & & $\%$ & 2,4 & 40,5 & 15,5 & 0 & 58,3 \\
\hline \multirow{2}{*}{\multicolumn{2}{|c|}{ Total }} & $\sum$ & 21 & 45 & 18 & 0 & 84 \\
\hline & & $\%$ & 25 & 53,6 & 21,4 & 0 & 100 \\
\hline \multicolumn{3}{|c|}{ Chi-Square } & \multicolumn{5}{|c|}{$P=0,000(p<0,05)$} \\
\hline
\end{tabular}

The table shows that the majority of respondents are 34 people $(40.5 \%)$ have a working period> 10 years who feel the musculoskeletal complaints of medium category.

Chi-Square test shows the value of $p=0,000$, where $p<0.05$ which means there is significant influence of work period against musculoskeletal complaints. 
Table 9. Cross tab Between Body Size / IMT With Musculoskeletal Complaint On Craftsmen Workers At Leather Craft Center Magetan

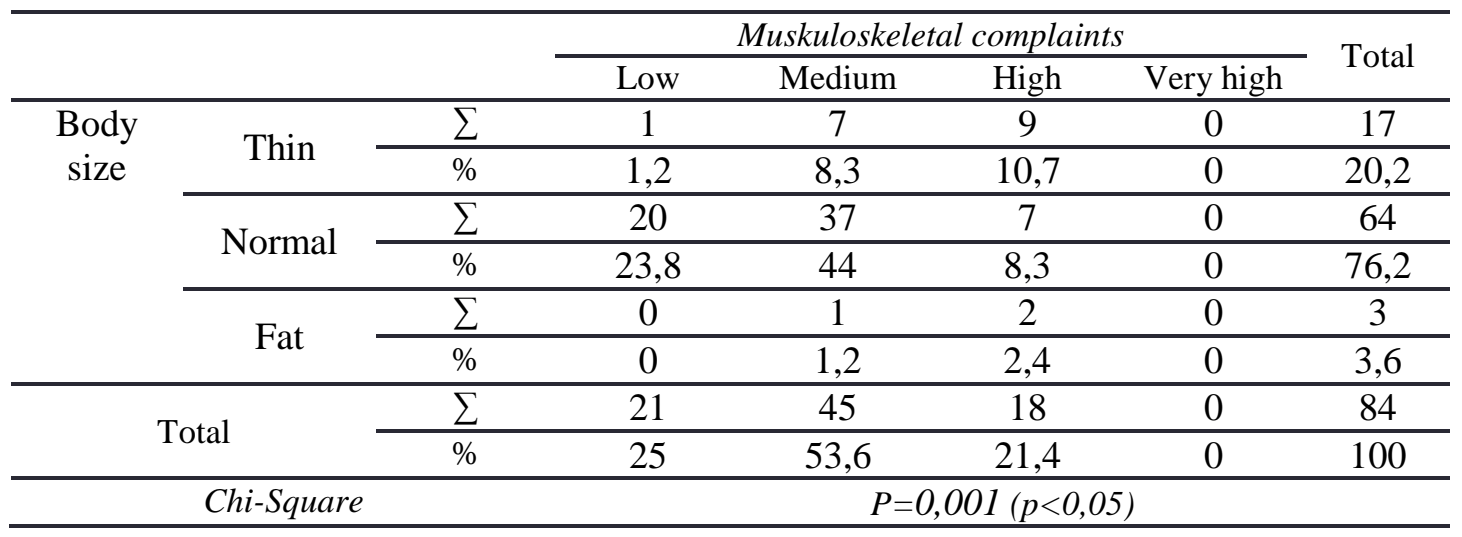

The table shows that most of the respondents, 37 people (44\%) had normal body size / IMT categories that felt moderate musculoskeletal complaints. Chi-Square test shows the value of $p=0.001$, where $p<0.05$ which means there is significant body size / IMT effect on musculoskeletal complaints

\section{MULTIVARIAT ANALYSIS}

Statistical analysis used to prove or test the research hypothesis is ordinal regression. Ordinal regression analysis results are as follows:

Table 10. Table Model Fitting Ordinal Regression Information

\begin{tabular}{ccccc}
\hline Model & -2 Log Likelihood & Chi-Square & Df & Sig. \\
\hline Intercept Only Final & $138,32650,583$ & 87,743 & 8 &, 000 \\
\hline
\end{tabular}

The result of ordinal regression analysis shows the value $p=0,000$, where $p<0,05$ meaning there is significant influence between work posture, duration, length of work, body size/BMI on musculoskeletal complaints.

Table 11. Table Pseudo R-Square Ordinal Regret

\begin{tabular}{lr}
\hline Cox and Snell &, 648 \\
\hline Nagalkerke &, 747 \\
\hline McFadden &, 517 \\
\hline
\end{tabular}

The results of analysis with ordinal regression, shows that the value Nagelkerke = 0.747 and Cox and Snell $=0.648$, which means that the diversity of data that can be explained by ordinal regression model is $64.8 \%$ of all existing data. 
Table 12. Estimates Parameter Table Ordinal Regression

\begin{tabular}{|c|c|c|c|c|c|c|c|c|}
\hline & & \multirow{2}{*}{ Estimate } & \multirow{2}{*}{ Std Error } & \multirow{2}{*}{ Wald } & \multirow{2}{*}{$\mathrm{df}$} & \multirow{2}{*}{ Sig. } & \multicolumn{2}{|c|}{$\begin{array}{c}95 \% \text { Confidence } \\
\text { Interval }\end{array}$} \\
\hline & & & & & & & $\begin{array}{l}\text { Lower } \\
\text { Bound }\end{array}$ & $\begin{array}{l}\text { Upper } \\
\text { Bond }\end{array}$ \\
\hline \multirow[t]{2}{*}{ Threshold } & [keluhan=1] & $-10,668$ & 2,382 & 20,057 & 1 & ,000 & $-15,337$ & $-5,999$ \\
\hline & [keluhan $=2$ ] & $-5,047$ & 1,935 & 6,801 & 1 & ,009 & $-8,840$ & $-1,254$ \\
\hline \multirow[t]{12}{*}{ Location } & [postur_kerja $=2$ ] & $-5,119$ & 1,350 & 14,373 & 1 &, 000 & $-7,765$ & $-2,472$ \\
\hline & [postur_kerja $=3$ ] & $-3,933$ & 1,170 & 11,288 & 1 & ,001 & $-6,227$ & $-1,638$ \\
\hline & [postur_kerja $=4]$ & $0^{\mathrm{a}}$ & & & 0 & , & 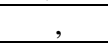 & , \\
\hline & [durasi=1] & $-3,365$ & 1,089 & 9,552 & 1 & ,002 & $-5,499$ & $-1,231$ \\
\hline & [durasi=2] & $-1,965$ & ,867 & 5,136 & 1 &, 023 & $-3,665$ &,- 266 \\
\hline & [durasi $=3$ ] & $0^{\mathrm{a}}$ & 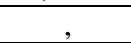 & s & 0 & 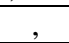 & 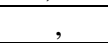 & , \\
\hline & [masa_kerja=1] & $-3,438$ & 1,026 & 11,232 & 1 & ,001 & $-5,448$ & $-1,427$ \\
\hline & [masa_kerja $=2]$ & $-1,737$ &, 731 & 5,643 & 1 & ,018 & $-3,169$ &,- 304 \\
\hline & [masa_kerja $=3$ ] & $0^{\mathrm{a}}$ & , & 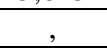 & 0 & 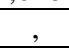 & 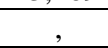 & 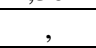 \\
\hline & {$[\mathrm{IMT}=1]$} &,- 679 & 1,685 & ,163 & 1 & 687 & $-3,982$ & 2,623 \\
\hline & [IMT=2] & $-1,633$ & 1,600 & 1,043 & 1 & ,307 & $-4,769$ & 1,502 \\
\hline & [IMT=3] & $0^{\mathrm{a}}$ & , & 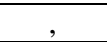 & 0 & & & , \\
\hline
\end{tabular}

The table shows that the variables influencing the musculoskeletal complaints, with the strongest influence of the work postures $(p=0,000$ and $p=0.001)$, the working period $(p=$ 0.001 and $p=0.018)$, and duration $(p=0.002$ and $p=0.023)$. While the body / IMT size variables $(\mathrm{p}=0.687$ and $\mathrm{p}=0.307)$ which means that body size / BMI has no effect on musculoskeletal complaints.

\section{DISCUSSION}

The Influence of Work Posture Against Musculoskeletal Complaint In Craftsmen Workers Of Shoes At Magetan Leather Craft Cente

Based on ordinal regression statistic test, $\mathrm{p}=0,000$ for medium-risk category work and $\mathrm{p}=0,001$ for high risk category work posture $(\mathrm{p}<0,05)$ which means there is significant influence from work posture to musculoskeletal complaints on shoemaker workers in center of Magetan leather craft. The results of this study are in accordance with research conducted by Yustica et al (2016) which mentions that there is a relationship between work posture with the level of subjective complaints musculoskeletal on Tembalang Semarang toll gate attendant caused by the sitting position of workers who tend to lean forward. Similarly, the results of research conducted by Wicaksono et al (2016) which mentions that there is a relationship between posture work with musculoskeletal complaints on students of architecture engineering Diponegoro University.

The results of the assessment on the work posture of respondents with RULA method showed that most respondents work with high risk posture category which means that the work posture of most of the respondents at high risk of causing musculoskeletal injuries characterized by musculoskeletal complaints felt by workers. This can be due to the work posture of respondents who are more often done with a position bent or leaning forward and neck that is too bowed. If this high-risk posture is done continuously for a long time it will increase the risk of musculoskeletal complaints. So the respondent really need to pay attention to his work posture. This means that remedial actions are needed to respond to the work done by respondents to prevent the occurrence of musculoskeletal complaints.

\section{Effect of Duration Against Musculoskeletal Complaint On Craftsmen Workers Of Shoe At Magetan Leather Craft Center}

Ordinal regression results show that $\mathrm{p}=0.002$ for short category duration and $\mathrm{p}=0.023$ for moderate category duration ( $\mathrm{p}<0.05$ ) which means duration significantly influence musculoskeletal complaints on shoemaker workers in skins of Magetan leather. This is in line 
with research conducted by Wicaksono et al (2016) which mentions that there is a relationship between duration with musculoskeletal complaints on students of engineering faculty majoring in architecture Diponegoro University.

According to Mukaromah et al (2017) mentioned that the duration of posture is not natural which is at risk of musculoskeletal disorder if maintained for more than 10 seconds. Thus it is seen that respondents who work with moderate duration (1-2 hours / day) in maintaining unnatural posture are at risk of causing musculoskeletal disorders because the duration exceeds the safe duration limit (> 10 seconds). The longer the duration of exposure, the greater the risk of musculoskeletal injury that will occur (Kantana, 2010 in Oktaviani, 2017).

In order to avoid the occurrence of musculoskeletal complaints caused by the length of duration of maintaining unnatural posture, the worker must change his posture more often. It can also be done by doing relaxation periodically as the body begins to feel tired. By frequent changes in posture and relaxation periodically, it can reduce the duration of maintaining unnatural posture or exposure to risk factors for musculoskeletal complaints. This means that the shorter the duration of exposure, the smaller the risk of musculoskeletal complaints that will occur.

\section{The Influence of Work Period Against Musculoskeletal Complaint On Craftsmen Workers Of Shoes At Magetan Leather Craft Center}

Based on ordinal regression statistical test results obtained $p=0,000$ for the working period $<5$ years and $p=0.018$ for the working period of 5-10 years, where $p<0.05$ which means the working period has a significant effect on musculoskeletal complaints on shoemaking workers in the center of Magetan leather craft. Musculoskeletal complaints that occur most of the respondents with tenure $>10$ years, because there has been accumulation of minor injuries that are neglected and considered not to interfere.

The results of this study in accordance with research conducted by Mukaromah et al (2017) which mentions the influence of working period against musculoskeletal complaints, the longer the working period of a person the more severe muscle pain experienced because the body muscles that work will adapt to the work process so the greater the risk of musculoskeletal complaints. Similarly, the results of research conducted by Mondigir et al (2017) mentions that there is a relationship between the working period with musculoskeletal complaints to fishermen in Kalinaun Village East Likupang District Minahasa Utara Regency.

Working period is one of the risk factors that can affect a worker to increase the risk of musculoskeletal complaints, especially for the type of work that uses high work force (Tarwaka, 2015). Skeletal muscle or musculoskeletal disorders (such as back pain) are usually part of a recurrent disease process with pain that tends to be more severe or worse, longer and more disruptive to work ability. The longer the work time the greater the risk of musculoskeletal complaints, this is because musculoskeletal is a chronic disease that takes a long time to develop and manifest (Tarwaka, 2015). The period of work is an accumulation of one's work activities done over a long period of time. Thus, the longer the work or the longer the worker is exposed to risk factors the higher the risk of musculoskeletal injury.

\section{Influence of Body Size / IMT Against Musculoskeletal Complaint On Craftsmen Workers Of Shoe At Magetan Leather Craft Center}

Based on the result of ordinal regression statistic test $\mathrm{p}=0,687$ for body size / BMI and $\mathrm{p}=0,307$ for body size / normal BMI, $(\mathrm{p}<0,05)$ meaning body size / BMI has no effect on musculoskeletal complaints on shoemaker workers in center of Magetan leather craft. Meanwhile, based on bivariate statistic test with Chi-Square showed that $p=0,001(p<0,05)$, which means body size / IMT significantly influence musculoskeletal complaints on shoemaking workers at skin care center Magetan. Musculoskeletal complaints associated with body size / IMT are more due to the balance conditions of the skeletal structure in accepting the weight of the body and other additional charges. 
This result is in line with research conducted by Brany et al (2017) which mentions that there is a strong and unidirectional relationship between musculoskeletal complaints with BMI. Similarly, the results of research conducted by Istighfaniar and Mulyono (2016) which states that the highest number of musculoskeletal complaints are in workers with normal BMI and the lowest number of complaints are also found in workers with normal BMI. This suggests that there is a relationship between BMI with musculoskeletal complaints. While the results of research conducted by Prawira et al (2017) showed that there is no significant relationship between nutritional status (BMI) with musculoskeletal complaints.

With the more fat a person then the risk of musculoskeletal complaints getting bigger. Although the effect of BMI on musculoskeletal complaints is relatively small, there is nothing wrong if workers pay attention to nutritional intake to maintain its nutritional status as a preventive effort against the occurrence of musculoskeletal complaints.

\section{CONCLUSION}

1. Most respondents, as many as 45 people (53.6\%) felt musculoskeletal complaints in medium risk category.

2. Most respondents, as many as 39 people (46.4\%) worked with unnatural working posture with high risk job of working posture and it significantly affected musculoskeletal complaints $(\mathrm{p}=0,000)$.

3. Most respondents, as many as 37 people (44\%) maintained unnatural working posture in medium duration category, in which it had significant effect on musculoskeletal complaints $(\mathrm{p}=0.000)$.

4. Most respondents, as many as 49 people $(58.3 \%)$ have $>10$ period of work, in which it had a significant effect on musculoskeletal complaints $(\mathrm{p}=0,000)$.

5. Most respondents, as many as 64 people (76.2\%) with normal body size / BMI in which it had a significant effect on musculoskeletal complaints $(\mathrm{p}=0.001)$.

6. There was effect of working posture, duration, years of service, body size / BMI on musculoskeletal complaints on shoe-craftsmen in leather craft center Magetan $(p=0,000)$. Therefore, based on the most powerful influence is the working posture; period of work; and duration.

\section{SUGGESTION}

1. For Research Site

a. Give more attention to the working attitude of the workers and the tools / equipment used in work.

b. Conducts coaching on workers periodically related to health risk factors and prevention efforts.

2. For Workers

a. Familiarize themselves to work with ergonomic posture, such as the position of the neck so as not to be too bowed, the body position does not bend, and use the seat with the back rest.

b. Familiarize themselves periodically to relax as the body begins to feel tired and pain.

c. Have the rest in accordance with the needs of the body.

3. For Further Researcher

The further research can conduct medical assessment / measurement of musculoskeletal complaints, in order to obtain objective data. 


\section{REFERENCE}

Alfara, I., Iftadi, I., \& Astuti, R.D. (2017). Analisis Postur Kerja Operator Perakitan Di Yessy Shoes Untuk Mengidentifikasi Resiko Gangguan Muskuloskeletal Akibat Kerja. Performa. Vol.16. No.1.

Brany, F., Doda, D.V., \& Boky, H. (2017). Faktor-Faktor Risiko Yang Berhubungan Dengan Keluhan Muskuloskeletal Pada Nelayan Di Desa Tuada Kecamatan Jailolo Kabupaten Halmahera Barat. Naskah Publikasi. Universitas Sam Ratulangi.

Dahlan, M.S. (2008). Statistik untuk Kedokteran dan Kesehatan. Edisi 3. Salemba Medika. Jakarta.

Efendi, A.S. \& Hafiza, S. (2017). Faktor Yang Berhubungan Dengan Keluhan Nyeri Punggung Bawah Pada Karyawan Redaksi Bagian Kantor Di PT. Riau Pos Intermedia Pekanbaru. MENARA Ilmu. Vol.XI. Jilid 1.

Harwanti, S., Aji, B., \& Ulfah, N. (2016). Pengaruh Posisi Kerja Ergonomi Terhadap Low Back Pain (LBP) Pada Pekerja Batik Di Kauman Sokaraja. Kesmasindo. Vol.8. No.1.

Hasriani, Y. (2016). Hubungan Postur Kerja Dengan Keluhan Muskuloskeletal Pada Pekerja di PT. Maruki Internasional Indonesia Makasar. Skripsi. Program Studi Fisioterapi Fakultas Kedokteran Universitas Hasanudin. Makasar.

Istighfaniar, K., \& Mulyono. (2016). Evaluasi Postur Kerja Dan Keluhan Muskuloskeletal Pada Pekerja Instalasi Farmasi. The Indonesian Journal of Occupational Safety and Health. Vol.5. No.1.

Kementerian Kesehatan RI. (2014). Pedoman Gizi Seimbang. Kementerian Kesehatan Republik Indonesia. Jakarta.

Mondigir, B.V.J., Malonda, N.S.H., \& Rumayar, A.A. (2017). Hubungan Antara Karakteristik Individu Dan Kebiasaan Merokok Dengan Keluhan Muskuloskeletal Pada Nelayan di Desa Kalinaun Kecamatan Likupang Timur Kabupaten Minahasa Utara. Naskah Publikasi. Universitas Sam Ratulangi.

Mukaromah, E., Suroto, \& Widjasena, B. (2017). Analisis Faktor Risiko Gangguan Muskuloskeletal Pada Pengayuh Becak (Studi Kasus Di Pasar Pagi Kabupaten Pemalang). JURNAL KESEHATAN MASYARAKAT (e-Journal). Vol.5. No.1.

Notoatmodjo, S. (2010). Ilmu Kesehatan Masyarakat (Prinsip-Prinsip Dasar). Rineka Cipta. Jakarta. 2012. Metodologi Penelitian Kesehatan. Rineka Cipta. Jakarta.

Octaviani, D. (2017). Hubungan Postur Kerja Dan Faktor Lain Terhadap Keluhan Muskuloskeletal Disorder's (MSDs) Pada Sopir Bus Antar Provinsi Di Bandar Lampung. Skripsi. Fakultas Kedokteran Universitas Lampung. Bandar Lampung.

Pangaribuan, D.M. (2009). Analisis Postur Kerja Dengan Metode RULA Pada Pegawai Bagian Pelayanan Perpustakaan USU Medan. Skripsi. Program Pendidikan Sarjana Ekstensi Departemen Teknik Industri Universitas Sumatera Utara. Medan.

Prawira, N.K., Yanti, N.P.N., Kurniawan, E. \& L.P.W. Artha. (2017). Faktor Yang Berhubungan Terhadap Keluhan Muskuloskeletal Pada Mahasiswa Universitas Udayana Tahun 2016. Journal of Industrial Hygiene and Occupational Health. Vol.1. No.2. 
Rosanti, E. \& Wulandari, D. (2016). Pengaruh Perbaikan Kursi Kerja Terhadap Keluhan Muskuloskeletal Pada Pekerjaan Menjahit Di Desa X. Journal of Industrial Hygiene and Occupational Health. Vol.1. No.1.

Santoso, \& Gempur. (2013). Ergonomi Terapan. Cetakan Pertama. Prestasi Pustaka Publisher. Jakarta.

Sentana, Putu, A.W., Sutrisna, \& I Ketut. (2013). Faktor-Faktor Yang Mempengaruhi Produktivitas Pekerja Pada Industri Kerajinan Sanggah Di Desa Jehem Kabupaten Bangli. EJURNAL EKONOMI PEMBANGUNAN UNIVERSITAS UDAYANA. Vol.2. No.8.

Sugiyono. (2012). Metode Penelitian Bisnis (Pendekatan Kuantitatif, Kualitatif, dan R\&D). Cetakan ke-16. Alfabeta. Bandung. 2012b. Statistika Untuk Penelitian. Cetakan ke20. Alfabeta. Bandung. Suma'mur, P.K. 2009. Ergonomic Untuk Meningkatkan Produktifitas Kerja. Edisi-Revisi III. Prestasi Pustaka. Jakarta.

Tarwaka, Solichul, H.A. Bakri, \& Sudiajeng, L. (2011). Ergonomi untuk Kesehatan, Keselamatan Kerja dan Produktivitas. Edisi-Revisi. UNIBA PRESS. Surakarta.

Tarwaka. (2015). Ergonomi Industri Dasar-Dasar Pengetahuan Ergonomi dan Aplikasi di Tempat Kerja. Revisi-Edisi II. Cetakan Kedua. Harapan Press. Surakarta.

Wicaksono, R.E., Suroto, B. \& Widjasena. (2016). Hubungan Postur, Durasi dan Frekuensi Kerja Dengan Keluhan Muskuloskeletal Akibat Penggunaan Laptop Pada Mahasiswa Fakultas Teknik Jurusan Arsitektur Universitas Diponegoro. JURNAL KESEHATAN MASYARAKAT (e-Journal). Vol.4. No.3.

Widyarti, \& Yustina. (2016). Analisis Risiko Postur Kerja Dengan Metode Quick Exposure Checklist (QEC) Dan Pendekatan Fisiologi Pada Proses Pembuatan Tahu. Publikasi Ilmiah. Universitas Muhammadiyah Surakarta.

Yustica, D.D., Suroto, \& Ekawati. (2016). Hubungan Antara Postur Kerja Dengan Tingkat Keluhan Subyektif Muskuloskeletal Pada Penjaga Pintu Tol Tembalang Semarang. JURNAL KESEHATAN MASYARAKAT (e-Journal). Vol.4. No.3. 